\title{
At blive lærer i den skolebaserede læreruddannelse
}

\author{
- om lærerstuderende på den skolebaserede lærer- \\ uddannelse og deres oversættelser og anvendelser \\ af læreruddannelsens teorier på deres vej mod at \\ blive lærere
}

\section{Anne Mette Hald, lektor, Ph.d., Professionshøjskolen Absalon, Læreruddannelsen, amh@pha.dk}

\begin{abstract}
Resumé
I den traditionelle læreruddannelse skal de lærerstuderende gennemgå et længere forløb på læreruddannelsen, før de får erfaring med skolens praksisser. For de lærerstuderende i den skolebaserede læreruddannelse ser det anderledes ud. De arbejder fra starten af deres uddannelse som lærere i en 1/3 lønnet stilling i en skole, samtidigt med at de uddanner sig til lærere. Dermed får deres erfaringer fra skolens praksisser i højere grad forrang. I denne artikel tages der afsæt i de lærerstuderende på den skolebaserede læreruddannelse og deres oplevelser og erfaringer med teori-praksisforbindelser og muligheden for oversættelse mellem dem. Der argumenteres for, at hvis erfaringer fra skolens praksis kommer først eller samtidigt, kan det bidrage til, at de studerende finder læreruddannelsens teoretiske viden relevant. Praksiserfaringerne kan spille en rolle som diskussionspartner til læreruddannelsens teoretiske viden.
\end{abstract}

Nøgleord: normativitet, teori-praksis, transition, skolebaseret læreruddannelse

\begin{abstract}
In the traditional teacher education, the students must gain theoretical knowledge before being exposed to a teaching situation where they apply this knowledge. For the teacher students in the school-based teacher education, it looks different. From the beginning of their education they work as teachers in a paid $1 / 3$ position in a school at the same time as they study the curricular at the teacher education. This gives priority to their experiences from the school over the theory from the teacher education. Based on the experiences of the teacher students at the school-based teacher education, this article explores the translation between the theory-based education and the practices they are exposed to during their education. The article argues that if the teacher students are exposed to the school's practices before or at the same time as the theoretical knowledge, then it can contribute to the students finding the teacher education's theoretical knowledge more relevant. The experiences with the school's practices can play a role as discussion partner to the theoretical knowledge.
\end{abstract}

Keywords: normativity, theory-practice, transition, school-based teacher education 


\section{Indledning}

I 2009 startede det første hold lærerstuderende på den skolebaserede lærereuddannelse (Schmidt \& Helms, 2010). De studerende arbejder i en 1/3 lønnet stilling i en skole, samtidigt med at de uddanner sig til lærere. De er på ugentlig basis dels på arbejde på en skole og dels på studie på læreruddannelsen. De pendler flere gange om ugen mellem skole og uddannelse. Samtidigheden er anderledes end den praktik, de øvrige studerende tilbydes og deltager i. Her deltager de studerende først på læreruddannelsen, hvorefter de i en kort periode får erfaringer fra skolens praksisser. Her kommer forskellige teorier om skolen før deltagelsen i skolens praksisser. I den skolebaserede læreruddannelse (herefter den SBL) er der en ugentlig vekselvirkning mellem deltagelse i skole og læreruddannelse, og derfor oplever de studerende på den SBL, at de konstant udfordres på at kunne oversætte forskellige former for viden fra uddannelsen til deres daglige praksisdeltagelser $\mathrm{i}$ skolen.

Den SBL har siden sin initiering i 2009 været unik for Danmark. Fra 2016 udbydes der dog forskellige varianter af den SBL på flere University Colleges i Danmark (Danske Professionshøjskoler, 2019), hvor de lærerstuderende arbejder i en deltidsstilling med løn i en skole under deres uddannelse. Den SBL stræbte fra starten efter at ophæve den dikotomiske opdeling af teoretisk viden for sig og praksisdeltagelse i skolen for sig. Den SBL er kendetegnet ved at have et samspil mellem de to i de studerendes uddannelsesforløb (Schmidt \& Helms, 2010; Hersom, 2010). Uddannelsen opstiller således et alternativ til den teoribasering af læreruddannelsens faglige curricula, som er resultatet af øget akademisering og evidensforankring, som de senere år har præget læreruddannelsen (Gulløv, 2015). Den SBL er teoretisk funderet, men med det særlige fokus, at de forskellige teorier i læreruddannelsen skal kunne relateres til skolens praksisser (Hersom, 2010), og dermed kan teorierne få en anden betydning (Hald, 2018). Artiklen undersøger, hvad dette betyder for de studerendes oplevelser og erfaringer med forskellige teori-praksisforbindelser. Artiklen skrives derfor med baggrund i dette forskningsspørgsmål:

Hvordan kan man forstå de lererstuderendes oplevelser og erfaringer med at oversætte og anvende uddannelsens forskellige teoretiske tilgange $i$ skolens praksisser $i$ den skolebaserede læreruddannelse? 


\section{Metodisk afsæt}

Artiklen bygger på forskning i min ph.d. (Hald, 2018), som er et etnografisk inspireret studie med deltagende observationer og interview med syv studerende fra den SBL i deres sidste år på læreruddannelsen og igen i deres første år som nyuddannede lærere, for at undersøge, hvordan de udviklede deres lærerfaglige læring og hvorledes de anvendte deres læring og teoretiske viden fra læreruddannelsen i deres arbejde som lærere. Observationer og interview blev foretaget på fire forskellige folkeskoler, hvor de studerende arbejdede. Observationsbilledet i artiklen er ét ud af over hunderede observationer foretaget over to perioder i løbet af to år. Der er foretaget 13 interview i løbet af to år, og artiklen inddrager udtalelser fra fire af de studerende $i$ analysen. Der er sket en anonymisering af de fire studerendes navne, idet de er blevet givet andre navne.

\section{Metodisk tilgang}

Interviewene blev udført på baggrund af en interviewguide. Den var blevet udfærdiget efter litteraturstudier, som kunne informere og kvalificere de forskellige interviewspørgsmål i guiden. Det betød dog ikke, at der ikke var åbenhed over for nye forståelser og nye spørgsmål, som opstod under interviewet (Tanggaard \& Brinkmann, 2010, s. 38), og at de fleste interview på trods af de teoretisk informerede interviewspørgsmål viste sig at blive en induktiv og problemorienteret proces. Intentionen med interviewundersøgelsen har været at lade de lærerstuderendes stemmer komme til orde og således at anlægge et førstepersonsperspektiv (Jacobsen et al., 2010), hvor de studerendes oplevelser og erfaringer med forskellig teori og forskellige praksisser står i centrum for undersøgelsen (se også Hald, 2018). Interviewene viste sig at medføre italesættelse af hidtil tavsgjort viden (Grensjö, 2003) og derved åbenbare de studerendes selvfremstillingsbilleder og forståelser af sig selv som kommende lærere. Det viste sig under interviewene, at de foretagne interview var velegnede til at udforske de studerendes forståelser af og begrundelser og målsætninger for deres arbejde, da de studerende spontant fortalte $\mathrm{om}$, hvordan de forstod og varetog deres arbejde på skolen, når de blev adspurgt om andre emner.

I observationsstudierne var genstandsfeltet de studerendes læring og deres tilblivelse til lærere. De blev udført på de skoler, hvor de studerende fra den SBL arbejdede som lærere. For at modgå bekendtskabs-problemet 
hos forskeren (Delamont, 2012, s. 6) arbejdedes der systematisk med en helhedsforståelse og en refleksionsproces, hvor jeg kunne konfrontere egen forforståelse og egne fordomme (Postholm \& Skrøvset, 2013, s. 508) ved at have så komplekst indblik i de studerendes hverdag som muligt. De studerende blev derfor fulgt ud af klasserummet, på gangen og på lærerværelseret og ind i klasserummet gennem flere hele dage.

\section{Analysestrategiske overvejelser}

Analysernes temaer i denne artikel er afledt af et samspil mellem det empiriske materiale og de teoretiske perspektiver, ud fra en overvejende analytisk induktiv tilgang (Boolsen, 2010, s. 208). Det er ikke objektive betragtninger, der lægges til grund for analysen, men de studerendes personlige vurderinger og oplevelser. Analyseprocessen har taget afsæt i at lade interview- og observationsmaterialet danne basis for analysens centrale temaer, for derefter at lade de teoretiske begreber informere materialet. I dialogen mellem empiri og teori og analysebærende begreber blev det tydeligt, at forholdet mellem forskellige teori-praksisforbindelser trådte frem. Analysen følger forbindelserne og undersøger, hvordan viden fra læreruddannelsens praksisser spiller ind i de studerendes nuværende praksisdeltagelse. Analysen er delt i to hovedafsnit, hvor den første analyse sætter fokus på, hvordan den normativitet, som de studerende oplever og opbygger på læreruddannelsen, kommer til syne, når de studerende handler i praksisser i skolen. I analysens anden del undersøges, hvordan forskellig teoretisk viden, der anvendes på læreruddannelsen, kan opleves som mere eller mindre aktuel og relevant af studerende, der i den SBL skal kunne håndtere aktiviteter i skolens praksisser på ugentlig basis.

\section{Teoretisk baggrund for undersøgelsen}

Sammenhængen mellem teori og praksis er diskuteret i politiske aftaler for folkeskolen (Børne- og Undervisningsministeriet, 2018), i lærebøger til læreruddannelsen (Lund \& Thingholm, 2018) og i lærebøger til diplomuddannelsen i erhvervspædagogik (Duch, 2019). Der er for nyligt nedsat et udviklingsarbejde fra regeringens side for at ændre læreruddannelsen, så der kan skabes en tættere sammenhæng mellem læreruddannelsens forskellige teorier og skolens praksisser (Uddannelses - og Forskningsministeriet, 2020). Forskning peger da også på, at flere lærerstuderende ople- 
ver en manglende sammenhæng mellem læreruddannelsens teori og de praksisser, de uddanner sig til at varetage (Nielsen, 2018; Haastrup et al., 2013; Darling-Hammond \& Bransford, 2008). Bidragene fra forskningen til undersøgelse af, hvorledes den oplevede diskrepans mellem teori og praksis i læreruddannelsen kan begrebssættes og overkommes, er omfattende (Johansen \& Frederiksen, 2013; Haastrup et al., 2013; Nielsen, 2014; Kamstrup, 2015; Knudsen, 2012). Nielsens forskning er et systematisk review af national og international forskning over tiltag til at forbedre og skabe sammenhæng mellem teori og praksis i fire udvalgte uddannelser. Hun gør opmærksom på, at en magtfuld konstruktion, som genfindes i megen forskning, er kløftmetaforen mellem teori og praksis, en kløft der skal bygges bro henover (Nielsen, 2014). Dette forsøger Kamstrup at imødegå gennem sin konstruktion af begrebet om teori-praksisfænomener, som hun kalder "t-p fænomener", hvor hun knytter de to begreber sammen for at overkomme dikotomien. T-p fænomener kan opstå som uadskillelige fænomener i professionsuddannelser (Kamstrup, 2015, s. 14). Kamstrup konkluderer, at "De studerende og underviserne bygger selv, både eksplicit og implicit, mange små broer kontinuerligt i løbet af deres hverdag (Kamstrup, s. 213). Den omtalte forskning peger således på den ene side på et magtfuld begreb til teoretisering af forholdet mellem teori og praksis og på en mulighed for at forlade begrebet og sætte andre teoretiseringer af forholdet i stedet. Denne artikel vil undersøge, om andre begreber kan give indsigter og forståelser af de læreprocesser, de studerende udvikler, når de skaber en sammenhæng mellem deres praksisdeltagelser og oversætter læring fra læreruddannelsens forskellige teorier til deres deltagelser i skolens praksisser.

\section{Analyseledende teoretiske begreber}

Dette afsnit undersøger, hvordan forskellige teoretiske begreber om, hvordan læring lært i en praksis kan anvendes i andre praksisser, kan bidrage til at undersøge, hvad der sker, når tilblivelsen til lærer udvikles i en læreruddannelse, hvor de studerende samtidigt med studiet arbejder i skolens praksisser. De begreber, der præsenteres, er forskellige forskningsbidrag til at begrebssætte oversættelsen af viden og færdigheder mellem forskellige kontekster. Oversættelsen kan begrebssættes som transfer (Wahlgren \& Aarkrog, 2012), som transition (Hager \& Hodkinson, 2009) og som transformation (Mezirow, 2000; Illeris, 2013). De forskellige begreber bliver i denne artikel 
analyseledende begreber, som kan hjælpe til at belyse, hvordan de studerende bliver lærere i den SBL.

Wahlgren \& Aarkrog definerer transfer af læring som "anvendelse af viden og kunnen lært i én sammenhæng til at kvalificere handling i en anden sammenhæng" (Wahlgren \& Aarkrog, 2012, s. 16). Der er tale om, at erhvervet viden fra en kontekst kan overføres til en ny kontekst. Citatet antyder, at der kan findes et sted med viden, hvor noget læres, og et andet sted med praksis, hvor det efterfølgende bruges. Wahlgren \& Aarkrogs definition kan medføre en hierarkisering af teori og praksis, hvor teorien foreskriver og foregriber praksis. Dette er ingen kontroversiel udtalelse. På den ordinære læreruddannelse tilbringer de studerende først noget tid på uddannelsen, og derefter deltager de i praktik på en skole. Der ligger den antagelse indbygget i uddannelsens politikpapirer, at det er muligt at lære at blive lærer på en uddannelse. Det er ifølge denne forståelse muligt at erhverve sig viden i en uddannelseskontekst, som skal overføres til og anvendes i en arbejdskontekst.

Transferbegrebet er blevet omfattende kritiseret af Hager \& Hodkinson (2009). De argumenterer for, at det ikke er det bedste begreb til at belyse de komplekse processer, der sker, når personer lærer og bevæger sig over i en ny kontekst og anvender læringen der. Begrebet har fokus på indhold fremfor på de lærendes læreproces. Det er mennesker, der bevæger sig, og ikke indhold, peger de to forskere på (Hager \& Hodkinson, 2009). De er stærkt kritiske over for ideen om læring som et fast, reificeret produkt, som personen en gang for alle tilegner sig og derefter kan bære med sig rundt i sine kontekster, for der sker ifølge de to forskere en udvikling, en transition, med det lærte, så det ikke længere er det samme. Det lærte er ikke et færdigt produkt, for det udvikles stadigt i nye kontekster. Der sker i overgangen fra en kontekst til en anden kontekst en transition af det lærte, så det lærte bliver anderledes. Under læringen ændres både indholdet i læringen og den lærende selv. Når den lærende konstruerer sin læring, så konstruerer hun også sig selv, argumenterer Hager \& Hodkinson for (2009, s. 633). De uddyber dog ikke, hvordan denne personlige forandring kan forstås nærmere, og derfor må et andet begreb hjælpe med forståelsen af den personlige forandring gennem læring.

Transformationsbegrebet tilbyder et begreb om identitetsforandrende læring (Mezirow, 2000; Illeris, 2013). Der er fokus på den lærende, som forandrer sig på grund af læringen. Det identitetsforandrende transformationsbegreb er blevet diskuteret af Knud Illeris i bogen Transformativ læring 
og identitet fra 2013, men begrebet stammer oprindeligt fra den amerikanske voksenuddannelsesforsker Jack Mezirow. Transformativ læring defineres af Mezirow som "den proces, der anvender en tidligere fortolkning til at konstruere en ny eller revideret fortolkning af meningen med ens erfaring som en guide til fremtidig aktivitet" (Mezirow, 2000, s. 5). Her medtænkes tidligere lærings indflydelse på det lærte. Transformationen indebærer en ny forståelse af, hvem man er som person, hvad man kan, ved og hvordan man forstår og har dermed identitetsskabende karakter. Læring foregår i Mezirows forståelse kognitivt og erkendelsesteoretisk. Hager \& Hodkinson kritiserer (2009, s. 628) transformationsbegrebet for at underbetone kontekstens betydning for det lærte. De overser således, at Mezirow teoretiserer en opmærksomhed over for kontekstens karakter af udløser og igangsætter af transformativ læring (Mezirow, 2000).

De tre begreber om læringsoverførsel kan hjælpe til at belyse de læreprocesser, de studerende i den skolebaserede læreruddannelse gennemgår under uddannelsen i deres tilblivelse til lærere. De kan bidrage til en empirisk baseret undersøgelse af, hvilken viden og hvilke færdigheder - der bidrager til de studerendes tilblivelse til lærere - der læres i henholdsvis læreruddannelsen og i skolens praksisser.

\section{Læreruddannelsens normativitet i skolens praksisser}

I analyseafsnittet undersøges forskningsspørgsmålet, der spørger til, hvordan de studerende i den SBL oversætter og anvender læreruddannelsens teorier i varetagelsen af aktiviteter i skolens praksisser. Empiriske eksempler fra en observation og forskellige interviewudtalelser vil belyse, hvordan de studerendes mere eller mindre forskellige praksisdeltagelser i skolen og på læreruddannelsen bidrager til, at de studerende udvikler sig til lærere.

\section{Observationsbillede. Anna underviser i tysk i 8. klasse}

Timen starter med, at Anna fortæller, at klassen skal have test i dag. Tre piger står oppe ved katederet $\mathrm{i}$ begyndelsen af timen og kommenterer Annas nederdel. Anna fortæller, hvor hun har købt den, og at den var billig. Pigerne sætter sig ned. Anna fortæller klassen, at de skal til Tyskland på en endagstur. Derpå giver 
Anna testen til eleverne og går rundt i klassen og deler testen ud. Flere elever sidder og arbejder med små høretelefoner i ørene. Hun giver tilladelse til, at eleverne bruger grammatikbøger, da de spørger efter dem, og hun siger henvendt til mig: "Selv om Henry (Annas tysklærer på læreruddannelsen) siger til mig, at jeg ikke må bruge dem". Anna går rundt i klassen og hjælper eleverne. Hun siger til eleverne: "To minutter mere, så gider vi ikke mere, vel? " Anna forlader lokalet og går ud efter computere til eleverne. Eleverne fortsætter med at arbejde med testen, mens de småsnakker lidt højere, end når Anna er i klassen. Anna kommer tilbage med en vogn med computere. Efter testen arbejder eleverne på computerne. Eleverne taler højt, og Anna siger, at eleverne skal lave noget, ellers bliver de sat til noget andet. Anna sætter sig et stykke tid hos en elev og derefter hos en anden. Anna kommer hen til mig og fortæller om en elev, der ikke kan læse, men som snakker godt tysk. Hun fortæller, at denne elev skal præsentere gruppens projekt og få en succesoplevelse på denne måde. Hun siger: "Det er godt, hun får succes på et område." Anna husker derefter fire elever på, at hun skal interviewe dem i morgen til sin bacheloropgave på læreruddannelsen. Timen er ved at slutte. Anna siger til en gruppe drenge: "Søde drenge, vær venlige at pakke jeres ting sammen nu." Anna forlader klassen sammen med mig og taler med mig på vejen til lærerværelset. Hun udtrykker stor usikkerhed om sit arbejde på skolen næste år. "Men nu skal jeg kun have én verden, én intra," siger hun. Der har ikke været én dag, hvor hun ikke har tænkt på sin bacheloropgave. Hun giver udtryk for stor dårlig samvittighed. Hun siger: "Jeg kan ikke producere hele tiden. Det har været det mest forfærdelige år, der har været i de fire år." Hun siger, da vi har gået lidt: "Bachelor, det jeg skriver om, gør jeg jo imens."

Observationsbilledet giver et eksempel på, hvordan viden og færdigheder fra læreruddannelsen sættes i spil i en undervisningspraksis i skolen. I observationen italesætter Anna en normativitet, som hun har beskæftiget sig med i en eller flere af læreruddannelsens praksisser. En stærk normativitet repræsenteret i forskellig teori i flere af læreruddannelsens praksisser handler om bestemte opfattelser af elever, af elevers læring og af elevers 
dannelse (Rasmussen et al., 2010). Begrebet normativitet dækker en række etiske antagelser om, hvad der er korrekt eller ukorrekt at gøre, hvad der er retfærdigt eller uretfærdigt at gøre, hvad der er passende og upassende at gøre, og hvad der er rigtigt og forkert at gøre og tænke. (Rouse, 2007, s. 46). I definitionen hos Rouse undgås en indholdsmæssig bestemmelse. En indholdsdrøftelse kan hentes hos Biesta (2014). På den ene side peger Biesta (2014, s. 88) på, at normativitet om bestemte opfattelser af elever og deres læring risikerer at placere og fastholde elever i, hvad der med Biesta begrebssættes som manglende emancipation. Denne normativitet argumenterer Biesta imod. Han fremhæver i stedet en anden normativitet med basis i lærernes skøn og dømmekraft. Det handler om "en form for læring, der konstant tager udgangspunkt i evnen til at foretage visse uddannelsesmæssige vurderinger" (Biesta, 2014, s. 182).

I sin undervisning trækker Anna på lærerfaglighed fra de pædagogiske fag, som hun opfatter dem. Hun vælger at komme elever i møde, når de vil danne relationer til hende, fremfor at overholde skolens regler om, at elever skal sidde stille på deres stole, mens læreren kan gå rundt i klasselokalet. Der er ifølge Kirkeby et al. (2005) en regel om forstoling i skolen, som det kræver lærerens tilladelse at bryde. Anna bryder skolens normative regler om, at elever skal sidde stille og være stille. Hendes mål med aktiviteten kan tolkes som anerkendelse og imødekommenhed. Regelbrydning i en given praksis er en del af regelkendskabet (Schatzki, 2012) og viser her, at Anna har lært skolens regler, og hvornår de kan brydes. Lidt senere i observationsbilledet kan det tolkes, at Anna ved at skabe sammenhænge mellem normativitet fra læreruddannelsen og sit skolearbejde udvikler en lærerfaglig kundskab i at undervise med denne normativitet. Hun italesætter en normativitet, der er fælles for læreruddannelsen og skolen, når hun siger: "Det er godt, hun får succes på et område". For Anna synes der ikke i denne udtalelse at være en kløft mellem det, hun har lært på læreruddannelsen, og det, hun har brug for at kunne i sin nuværende praksisdeltagelse. Der synes at være en sammenhæng i hendes tænkning, som hun præsenterede den.

Når Rasmussen et al. (2010) kritiserer dansk læreruddannelse for at anvende (for) meget litteratur om normativitet i skolen, har de ikke medtænkt, at netop normativiteten kan skabe en sammenhæng mellem (noget) teoretisk viden i læreruddannelsens praksisser og de studerendes deltagelsesformer i skolen. Når den studerende efter en transitionsproces oversætter læreruddannelsens teori om normativitet i skolen til brug i skolen, kan det udvikle en lærerfaglig kundskab i at handle med normativitet, der skaber en 
rummelig opmærksomhed over for alle elever hos den studerende. Kundskaben $\mathrm{i}$ at handle med normativitet handler om at træffe etiske afgørelser til glæde for eleverne. Biesta beskriver denne form for lærerfaglig kundskab som "praktisk visdom for at kunne vurdere, hvad der er behov for at gøre" (Biesta, 2014, s. 25). Det er vigtigt at pointere, at kundskaben i at handle med normativitet ikke medfører en bestemt måde at handle på. Men det er evnen og holdningen til at kunne opdage, hvad der gavner den enkelte elev i situationen, og handle i overensstemmelse med egne værdier og egen dømmekraft (Gulløv, 2015) og en dømmekraftbaseret tilgang til undervisning (Biesta, 2014).

Midt i timen taler Anna med nogle elever om et interview, hun skal lave med dem senere. Anna bringer sine egne faglige aktivitetskrav fra læreruddannelsen ind i en sammenhæng med elevernes faglige aktiviteter, når hun under elevernes faglige aktiviteter bryder ind med sit spørgsmål om interview til sin bacheloropgave. Hun udbryder om kravet omkring bacheloropgaven, at "det, jeg skriver om, gør jeg jo imens ". Der er en mulighed for læring i Annas deltagelse i læreruddannelsen og skolens praksisser samtidigt. Hun italesætter spontant en sammenhæng, som hun selv skaber med sin bacheloropgave. Der synes ikke at være de grænser, som Akkerman \& Bakker (2012) teoretisk sætter op mellem praksisser for Anna. Hun kan uden anstrengelse knytte sammenhæng uden at skulle over en grænse eller en kløft.

Anna uddyber i et interview sin forståelse af, hvordan normativiteten om dannelse af elever, som der arbejdes med i videnindholdet (Lund \& Nielsen, 2020, s. 143) i de pædagogiske fag, spiller en væsentlig rolle i hendes læreproces. Hun fortæller:

\section{"Det, der har rykket mest ved mig, så er det måske, hvilken dannelse vi vil, vi ønsker at uddanne vores elever til, for det har jeg slet ikke den fjerneste tanke haft en ide om, egentligt så har jeg måske været meget konservativ i min opfattelse, jeg kommer fra en privat skole, med den gamle behavioristiske tilgang, hvor udenadslære var det, vi lærte, ikke, det har så også gjort, at jeg ikke interesserer mig overhovedet, det der ved at ruske ved vores egne forestillinger om, hoad er det, vi vil med eleverne, og det kan man sige, det ligger meget i forskellige pxdagogiske fag."}


Den teoretiske normative viden har forandret Annas for-forståelser, hvilket kan indikere, at der er tale om en transformativ læreproces, hvor den lærende får stillet spørgsmålstegn ved sine hidtidige forståelser (Mezirow, 2000). At hun bruger begrebet "ruske ved vores egne forestillinger" angiver, at hun har været igennem en krævende og identitetsforandrende transformativ læreproces. I en transformativ læringsproces er forandringer mere omfattende og kræver større energi af den lærende end andre former for læring. Det er kendetegnede for den transformative læring, at den omfatter skift i eget perspektiv og forståelse (Mezirow, 2000), hvilket Anna udtrykker at have opnået. Der kan derfor argumenteres for, at Annas transformative læring er en del af hendes lærerfaglige kundskab i at handle med normativitet. Anna udtrykker også sin tranformative læreproces på læreruddannelsen på en anden måde. Hun siger:

"men nogle af de der teoretikere, når vi går lidt for langt tilbage (griner)
nogle gange så tænker jeg arrrr (lydord), Habermas og Bourdieu og
sådan noget, jeg kan da godt se, der er et eller andet i det, men et eller
andet sted kan det godt være, uden at jeg er klar over det, at det allige-
vel har rykket noget ved og fäet mig til at tænke pånoget andet, ikke,
altså at tænke, jeg ville nok egentligt før i tiden have skudt meget mere
på, at de skulle være fagligt dygtige, når de kom ud, eleverne, hvor jeg
absolut er gået mere over til, at det er nogle andre kompetencer, at det
er faktisk noget andet, jeg gerne vil uddanne dem til, ikke, altså de skal
anerkende hinanden, de skal have interkulturel kompetence, og sådan
nogle ting har jeg overhovedet ikke skænket en tanke før, og det må jeg
sige, det har det været med til."

Nogle teoretikere som Habermas og Bourdieu synes i første omgang at være irrelevante i forhold til Annas praksisdeltagelse, er hendes umiddelbare reaktion. Alligevel er der noget teoretisk viden, der har med Habermas og Bourdieu at gøre, som har bevirket en læreproces og en holdningsændring. Det har forandret Anna at beskæftige sig med de pædagogiske teorier, for inden hun gjorde det, var hendes overbevisning anderledes. Tidligere var hun tilhænger af, at eleverne skulle opnå høj faglighed. Men nu er det forandret til, at eleverne skal uddannes til anerkendelse og interkulturel kompetence. Der er et klart før og efter læringen, som har medført opgør med egne antagelser (Mezirow, 2000) om, hvad elever skal kunne. Nu er normative opfattelser af, hvilke værdier hun vil viderebringe til eleverne mere vigtigt. 
Dermed har de nutidsfjerne teorier alligevel bidraget til Annas lærerfaglige kundskab i at handle normativt, når hun i interviewet får italesat sin tavsgjorte viden (Grensjö, 2003).

Også de andre lærerstuderende i undersøgelsen anvender normativ læring fra læreruddannelsen, når de forholder sig til eleverne. I Louises undervisningspraksis væves normativiteten fra læreruddannelsen ind. Hun siger:

\begin{abstract}
"også i forhold til, når vi snakker empati, jamen, der bruger jeg også mange af de ting, vi har læst på seminariet, både i forhold til psykologi og pædagogik, hvordan kan jeg tackle det barn her, hoad kan jeg gøre, de her relationer, som vi også har meget oppe i klassen, hvorfor er de så vigtige, og hoad kan jeg gøre, og hvordan og hvorledes kan jeg gøre, $j a$, så selv om jeg sagde før, at man har noget af natur, og lærer noget gennem relationer, så er der også noget fra lærerseminariet, man kan tage dem der, en hel del både fra pædagogik og psykologi og almen didaktikken, den kommer så ind $i$, hvordan jeg udfører det her, men det synes jeg sådan er mere overordnet, planlægning og sådanne nogle ting."
\end{abstract}

I citatet angiver Louise, at hun trækker på lærerfaglig læring fra multiple praksisser (Schatzki, 2012), når hun handler med normativitet i klasserummet. Hun trækker på læring fra pædagogiske fag i læreruddannelsen, men ikke kun. Hun trækker også på, hvad hun har lært gennem sine relationer til eleverne i skolens praksis, og desuden trækker hun på det, hun kalder sin natur, som kan tolkes som hendes tidligere læring. Hager \& Hodkinson henviser til Dewey, når de pointerer, at den lærende bringer meget mere end viden og færdigheder ind i deres nye praksisdeltagelse. De medbringer også deres personlige erfaring (Hager \& Hodkinson, 2009, s. 631). Louise kan tolkes at have gennemgået en transition, hvor hun har dannet kundskab i at handle med normativitet i relationen til elever ved at bringe viden fra læreruddannelsen i sammenhæng med sine erfaringer fra skolens praksisser og sin tidligere læring.

En tredje lærerstuderende i undersøgelsen, Signe, peger ligeledes på, hvordan teoretisk normativ viden fra de pædagogiske fag har bidraget til holdningsdannelse. Signe siger: "Det, vi har lært på seminariet, det er med til, at jeg reflekterer over, hvordan jeg gerne vil være som lærer." Signe danner normativitet om sin lærerrolle, og i den proces spiller teorier fra 
læreruddannelsens praksisser en rolle. Det kan tolkes, som hun gennem går en transition, hvorigennem hun danner sin personlige forståelse af det lærte. Det er teorier med overvejelser og normativiteter om lærerrollen, som er vigtigt for hende.

Den empirisk baserede analyse viser, at læreruddannelsens teoretiske viden for nogle af de studerende i den SBL udvikler kundskab i at handle med normativitet. Begrebet teoretisk viden kan begrebssættes på forskellige måder. Haastrup et al. (2013, s. 7) begrebssætter teori som "overvejelser, planer, refleksioner, empiriske forskningsresultater, begreber, metoder, antagelser, viden om lovmæssigheder m.m." De tilføjer: "Teori kan være optik eller begrebsapparat at se verden med, teori kan være kritik af praksis, tekniske anvisninger, fortolkninger af praksis, refleksioner over praksis, eller den kan opstille idealer for praksis m.m." (Haastrup et al, 2013, s. 7). De studerende i den SBL skelner mellem faglig og fagdidaktisk viden og pædagogisk og psykologisk viden. Begge disse former for viden kategoriserer Lund \& Nielsen (2020) som videnindhold. Ingen af de studerende henviser til empiriske forskningsresultaters viden, når de bliver interviewet om, hvordan læreruddannelsens teori har spillet en rolle i deres lærerarbejde. Det betyder ikke, at de ikke har anvendt empirisk forskningsviden, men det er ikke denne videntype (Lund \& Nielsen, 2020, s. 143), der dukker først op i deres forståelser af sig selv som lærere, når de italesætter deres viden.

\section{Mere eller mindre skolerelevant viden fra læreruddannelsen}

De studerende der indgår i analysen oplever således, at forskellige teorier i læreruddannelsen kan udvikle læreprocesser, hvis den introducerer normativitet. Andre former for teoretisk viden i læreruddannelsen kan også iværksætte læreprocesser af forskellig art. Anna siger:

"at nu kommer jeg til at tænke på min tyskundervisning, som jeg havde sidste år, det var det mest fantastiske, jeg har haft oppe på seminariet, jeg har haft så mange ting, måske også fordi jeg var herude, men de ting, jeg fik $i$ undervisningen oppe pà seminariet, kunne jeg tage næsten direkte med mig ud i undervisningen og fä afprovet $i$ tysk og fä prøvet af og se, og måske lige lave, jeg laver lige en lille justering her, men ellers kunne jeg gøre det, næsten som det var deroppe, og det er jo selvfølgelig, fordi jeg har siddet deroppe og lært det." 
Anna har oplevet teoretisk viden i tyskfaget som praksisrelateret, og derfor har det givet mening for hende. Anna oplever at kunne overføre sin viden fra en kontekst til en anden. Er det transfer? Aarkrog \& Wahlgren peger på betydningen af "at kunne anvende det lærte i direkte forlængelse af læringssituationen (Wahlgren \& Aarkrog, 2012, s. 132). I transfermetaforen er der en relativ simpel forståelse af overførsel, hvor den lærende tilegner sig læring eller en kompetence, som "man kan anvende i en anden og ny sammenhæng" (Wahlgren \& Aarkrog, 2012, s. 9). Citatet fra Anna viser, at hendes læreproces forløber komplekst. Der sker en forandring af det lærte, så det ikke længere er det samme. Anna har ikke tilegnet sig en bestemt viden. Hun kan tolkes at have udviklet en læreproces på baggrund af sine erfaringer fra skolen, hvor hun gennem en transitionsproces har fået sin egen forståelse af den teoretiske viden fra tyskfaget, så hun efterfølgende kan anvende den viden i sit arbejde i skolen. Begrebet transition kan belyse, at der i læreprocessen sker en forandring med den lærte viden. En transitionsproces, der starter, fordi hun allerede har viden fra skolens praksisser eller med hendes ord "fordi jeg var herude".

Signe siger om indholdet i teorien fra de pædagogiske fag på læreruddannelsen, at:

\section{"hvis nu man samler lidt fra hist og pist og finder ud af, hoad der passer mig, også de, det gode ved uddannelsen var jo også, at du kunne tage de her problemstillinger med, jeg har også den her elev, som bare ikke vil noget $i$ det her fag, så det tager jeg med, og så diskuterer jeg det i psykologi, eller hoad det nu ellers er, man har, og så får man ligesom noget teori på, som ligesom underbygger ens ideer og ens tanker."}

Videnindholdet kan Signe bruge, hvis hun har anden viden og erfaringer fra skolen med til undervisningen på læreruddannelsen, som kan være hendes ideer om og erfaringer med elever. Hvis Signe har fået erfaringer i skolens praksisser, så kan der skabes yderligere viden i læreruddannelsens undervisningstid. Det kan ske, når hun præsenteres for forskellig teoretisk viden af underviseren, som udvirker refleksion over praksisdeltagelsen hos Signe, og derved skabes der en forbindelse mellem praksisdeltagelsen og teorien.

Praksisdeltagelsen kommer før den teoriske bearbejdning i Signes læreproces, som hun beskriver den i citatet, og den bliver i hendes forståelse en diskussionspartner til den teoretiske viden. Anna udtrykker det samme, når hun siger: "Du kan bruge din teori til at reflektere over noget, når du ople- 
ver det, men jeg mener faktisk, det er den vej mest rundt, det går, oplevelse og så kommer teorien bagefter." Deltagelsen i skolens praksisser bliver også her forudsætningen for, at den teoretiske viden i læreruddannelsen kan få relevans og mening. En fjerde lærerstuderende, Jonas, argumenterer tilsvarende, når han siger: "Men hvis jeg ikke havde set det, så havde det bare været teori, men jeg har set det her." Jonas har haft oplevelser i skolens praksis, som medfører, at teoretisk viden godt kan give mening og få relevans for ham.

Begrebet om transition kan begrebssætte den meningstilskrivelse, som Jonas gennem sin læreproces omformer den lærte viden efter. Det støtter tolkningen af citatet som transition, at han anvender sine erfaringer for at forstå det lærte. Uden oplevelserne ville forskellige former for viden i læreruddannelsen have været meningsløse for Jonas og "bare været teori". Teoretisk viden af forskellig art i sig selv udvirker ikke indsigt hos Jonas, mens teoretisk viden om fænomener, han kan genfinde i sine praksisser, gør. Både Anna, Signe og Jonas udtrykker, at hvis der skal skabes sammenhæng mellem læring på de to lokationer, så sker det bedst mellem erfaringer fra skolens praksis og læreruddannelsens teori og ikke omvendt.

Men det er ikke al teoretisk viden i læreruddannelsens praksisser, der kan give mening. Louise fortæller, hvordan hun opfatter den matematikundervisning, hun har deltaget i på læreruddannelsen. Jeg spørger: "Hvor meget har det betydet for dig, at du har linjefag i matematik?" og Louise svarer: "Ingenting, overhovedet, jeg har faktisk også været inde omkring ledelsen og sige, at i forhold til matematiklinjefag, at det, at jeg har læst det, har ikke gjort mig til en dygtigere underviser." Louise mener, at hun ikke kan varetage en undervisning i matematik på baggrund af sin læreruddannelse. Hvad kan det skyldes? Med Dewey kunne der svares, at Louises problem er, at hendes oplevelser med den teoretiske viden i matematik har haft en mangelfuld og forkert karakter i forhold til hendes erfaringer fra skolens praksisser og derfor ikke kan indgå i en erfaringsdannelse (Dewey, 2008).

Der er lærerfaglig læring og kompetenceudvikling, der ifølge de studerende alene kan læres i skolens praksisser. Anna uddyber denne forståelse i et interview: "Du kan ikke lære om relationskompetence, du kan høre en masse teori om det, men du kan ikke lære at danne relationer oppe på seminariet, altså det tror jeg ikke på, du kan lære, det kan du ikke ved teori." Relationer til elever lærer Anna i skolens praksisser og ikke i læreruddannelsens praksisser. Louise, som præsenteredes ovenfor, mener, at der findes teori "både fra pædagogik og psykologi", der også bidrager til at danne rela- 
tioner. Men selve relationsdannelsen med eleverne og udviklingen af relationskompetence foregår og læres bedst i skolens praksisser, mener de begge to.

\section{Diskussion}

Hvis oplevelsen af kompleksiteten og mangetydigheden i skolens praksisser er det bedste udgangspunkt for en forståelse af, hvad forskellig teoretisk viden kan og skal, kan det undre, at de lærerstuderende skal kende til teoretisk viden, før de kan anvende denne viden i skolen, og at uddannelsen derfor skal komme lang tid før praksisdeltagelse. Dette gælder for den pædagogiske viden, den didaktiske viden og den fagdidaktiske viden, som alle er former af den viden, som Lund \& Nielsen begrebssætter som videnindhold (2020, s. 143), og som analysen peger på, at de studerende i den SBL kan oversætte og anvende i deres arbejde i skolen, efter de har gennemgået forskellige læreprocesser. For de lærerstuderende i den SBL har erfaringer fra skolens praksisser forrang. Dette bakkes op af Laursen (2008), som argumenterer for, at læreruddannelsens teori kan spille en rolle som diskussionspartner til praksiserfaringerne. De studerende i den SBL peger på, at det ofte går den anden vej, nemlig at praksiserfaringer bliver diskussionspartner til læreruddannelsens teori. Det samme fænomen ses i forskning om læreruddannelser, der inkluderer langt mere deltagelse i skolens praksis. Når erfaringer fra skolen kommer først eller samtidigt, aktualiserer det læreruddannelsens teori (Lejonberg et al., 2017, s. 69).

De studerende omtaler dog også ulemper ved at deltage på den SBL. Jonas siger: "og med jeg har været her på den skolebaserede, har mit fokus også meget ligget her, fremfor at det har ligget på det fag-faglige på seminariet." Hvis de studerende ikke får udfordret deres naturaliseringer fra skolens praksisser i undervisningen på læreruddannelsen, så kan den SBL medføre socialiseringsprocesser til den bestemte skoles værdier frem for læreprocesser. Louise oplever, at "man hurtigt kan skubbe seminariet lidt væk, fordi man er så tæt tilknyttet en arbejdsplads." Skolens praksisser kan blive vigtigst og udkonkurrere deltagelsen i læreruddannelsens praksisser (Schmidt \& Helms, 2010). Derfor skal praksiserfaringerne i den SBL indgå i diskussion med læreruddannelsens teori, som kan udfordre og forklare praksiserfaringerne. 


\section{Konkluderende bemærkningen}

På den ene side har analysen vist, at de studerende uden anstrengelse kan bringe normativiteten fra læreruddannelsens praksisser ind på skolen. De studerende oplever ikke grænser eller kløfter mellem læring i læreruddannelsens praksisser og anvendelse af læringen i skolens praksisser, når det gælder normativitet. Dette støttes af Hager \& Hodkinson, der peger på, at forskning viser, at overgangen fra skole til arbejdsplads ofte foregår uproblematisk (2009, s. 634). Normativiteten fra læreruddannelsens praksisser kan endvidere medføre transformativ læring. Anna har gennem beskæftigelsen med normativitet fra læreruddannelsens praksisser grundlæggende ændret sit syn på elevernes dannelsesproces og udviklet kundskab i at handle med normativitet. Derfor er det en pointe, at normativiteten i læreruddannelsen ikke skal reduceres eller erstattes af evidensbaserede forskningsresultater, som Rasmussen et al. (2010) foreslår. Normativiteten kan derimod supplere forskningsbaseret viden i læreruddannelsen, så det ikke bliver et enten-eller men et både-og.

På den anden side har analysen peget på et stort potentiale i at iværksætte en forbindelse mellem skolens praksisser og læreruddannelsens teoretiske viden fra starten af uddannelsen. Den SBL giver fra starten af uddannelsen de studerende et særligt indblik i den profession, de uddannes til at varetage, hvilket giver de studerende en mulighed for at forstå læreruddannelsens teoretiske viden og finde den relevant, hvad de ordinære studerende ikke har samme mulighed for at opnå. Analysen af de studerendes forståelser og oplevelser kan pege på potentiale for den læringsudvikling til at blive lærer, der kan opstå, hvis der blev indført mere, tidligere og samtidig skoledeltagelse. Forskning i den SBL har vist, at organiseringen af den SBL støtter de studerendes læreprocesser (Hald, 2018). Når de studerende i den SBL oplever skolens praksisser først eller samtidigt med deres deltagelse i læreruddannelsens praksisser, så kan teoretisk viden opleves som meningsgivende og anvendes i deres praksisdeltagelser i skolen.

\section{Referencer}

Akkerman, S. F., \& Bakker, A. (2012). Crossing Boundries between School and Work During Apprenticeship, Vocations and Learning, 5, 153-173.

Alvesson, M., \& Sköldberg, K. (2008). Tolkning och refleksion. Vetenskapsfilosofi och kvalitativ metod. Studentlitteratur.

Biesta, G. J. J. (2014). Den smukke risiko I uddannelse og pædagogik. Forlaget Klim. 
Hald: At blive lærer i den skolebaserede læreruddannelse

Boolsen, M. W. (2010). Kvalitative analyser. At finde årsager og sammenhænge. Hans Reitzels Forlag.

Borgnakke, K. (2013). Etnografiske metoder i uddannelsesforskningen-mellem klassiske traditioner og senmoderne udfordringer. Københavns Universitet.

Danske Professionshøjskoler (2019). Fakta om læreruddannelsen. https://danskeprofessionshøjskoler.dk/wp-content/uploads/2019/06/Fakta-om-1\%C3\%A6reruddannelsen.pdf

Darling-Hammond, L., \& Bransford, J. (red.) (2005). Preparing Teachers for a Changing World. What teachers Should Learn and Be Able to Do. Jossey-Bass.

Delamont, S. (2012). Introduction: Leaving Damascus. I: Delamont, S. (red.), Handbook of Qualitative Research in Education (s. 1-20). Edward Elgar.

Dewey, J. (2008). Erfaring og opdragelse. Hans Reitzels Forlag.

Duch, H. (2019). På diplom. At lære som voksen. Gyldendal.

Grensjö, B. (2003). Pedagogik i arbetslivet; Tysta, tystnande och tystade kunskaper. Pedagogiska institutionen, Umeå Universitet.

Gulløv, J. (2015). Dømmekraft i praksis. En antropologisk undersøgelse af professionelle på en skole. Ph.d. afhandling. Roskilde Universitet

Haastrup, L., Hasse, C., Jensen, T. P., Knudsen, L. E. D, Laursen, P. F., \&Nielsen, T. K., (2013). Brobygning mellem teori og praksis i professionsbacheloruddannelserne - Sammenfattende rapport. KORA

Hager, P., \& Hodkinson, P. (2009). Moving beyond the metaphor of transfer of learning. British Educational Research Journal, 35(4), 619-638.

Hald, A. M. (2018). At blive en kompetent lærer. Et praksisbaseret studie af nye læreres håndteringer af ekstra-curriculære aktiviteter. Ph.d. afhandling. Roskilde Universitet.

Hersom, H. (2014). Den skolebaserede læreruddannelse - læring via praksis? Anden evalueringsrapport. Roskilde Universitet.

Illeris, K. (2013). Transformativ læring og identitet. Samfundslitteratur.

Jacobsen, B., Tanggaard, L., \& Brinkmann, S. (2010). Kvalitative metoder: En grundbog. Hans Reitzels Forlag

Johansen, B. M., \& Frederiksen, L. L. (2013). Teori og praksis i de danske professionsuddannelser. Nordisk barnehageforskning, 6, 1-12.

Kamstrup, A. K. (2015). Teori og praksis som fxnomener; en empirisk analyse af hoordan teori og praksis bliver til på lærer- og diplomingeniøruddannelsen. Ph.d.-afhandling. Institut for Uddannelse og Pædagogik, Aarhus Universitet.

Kirkeby, I. M., Gitz-Johansen, T., \& Kampmann, J. (2005). Samspil mellem fysisk rum og hverdagsliv i skolen. I: Larsen, K. (red.), Arkitektur, krop og læring (s. 43-68). Hans Reitzels Forlag.

Knudsen, L. E. D. (2012). Teori og praksis i læreruddannelsen: kundskabsformer, kultur og kropslighed. Ph.d.-afhandling. Institut for Uddannelse og Pædagogik, Aarhus Universitet.

Laursen, P. F. (2008). Det er i praksis, man virkelig lærer noget. I: Bjerregaard, H. (red.), Tango for to; teori og praksis i læreres professionsudvikling (s. 39-60). Dafolo.

Lejonberg, E., Elsted, E., \& Hunskaar, T. S. (2017). Behov for å utvikle «det tredje rom» $\mathrm{i}$ relasjonen mellom universitet og praksisskoler. Uniped, 40(1), 68-85.

Lund, H. J., \& Nielsen, L. B. (2020). Viden i læreruddannelsen - en analysemodel. Studier $i$ læreruddannelse og -profession, 5(1), 135-156.

Lund, L., \& Thingholm, H. B. (red.) (2018). Empirisk Didatik. Udfordringer, refleksioner og potentialer i forskellige pædagogiske praksisser. Dafolo.

Mezirow, J. (2000). Learning to Think Like an Adult: Core Concepts of Transformation Theory. I: Mezirow, J. \& Associates (red.), Learning as Transformation (s. 3-34). JosseyBass. 
Nielsen, T. K. (2014). Teori og praksis i professions-bacheloruddannelserne; Et systematisk review. Ph.d.-afhandling. Institut for Uddannelse og Pædagogik, Aarhus Universitet.

Postholm, M. B., \& Skrøvset, S. (2013). The Researcher reflecting on her own role during action research. Educational Action Research 21(4), 506-518.

Rasmussen, J., Bayer, M., \& Brodersen, M. (2010). Komparativt studium af indholdet i læereruddannelser i Canada, Danmark, Finland og Singapore. Rapport til Regeringens Rejsehold. Danmarks Pædagogiske Universitetsskole, Aarhus Universitet.

Rouse, J. (2007). Social Practices and Normativity. Philosophy of the Social Sciences 37(1), $1-11$.

Schatzki, T. R. (2012). A Primer on Practices. I: Higgs, J, Barnett, R., Billett, S, Hutchings, M., \& Trede, F. (red.), Practice-Based Education Perspectives and Strategies (s. 13-26). Springer.

Schmidt, C., \& Helms, S. (2010). Følgeforsknings- og udviklingsprojekt om Den skolebaserede læreruddannelse ved University College Sjælland (UCSJ), Første evalueringsrapport. Roskilde Universitet.

Tanggaard, L., \& Brinkmann, S. (2010). Interviewet: Samtalen som forskningsmetode. I: Brinkmann, S., \& Tanggaard, L. (red.), Kvalitative metoder: en grundbog (s. 463-479). Hans Reitzels Forlag.

Uddannelses- og Forskningsministeriet (2020). Nytænkning af læreruddannelsen - et ambitiøst udviklingsarbejde. https://ufm.dk/aktuelt/pressemeddelelser/2020/filer/ notat-om-udvikling-af-laereruddannelsen.pdf

Wahlgren, B., \& Aarkrog, V. (2012). Transfer. Kompetence i en professional sammenhæng. Aarhus Universitetsforlag. 